\title{
Is Duane retraction syndrome part of the VACTERL association?
}

This article was published in the following Dove Press journal:

Clinical Ophthalmology

19 March 2013

Number of times this article has been viewed

\author{
Serpil Akar \\ Birsen Gokyigit \\ Isilay Kavadarli² \\ Ahmet Demirok' \\ 'Pediatric Ophthalmology and \\ Strabismus Department, Prof Dr \\ $\mathrm{N}$ Reșat Belger Beyoglu Education \\ and Research Eye Hospital, Istanbul, \\ ${ }^{2}$ Department of Ophthalmology, \\ Gaziantep, Kilis State Hospital, Kilis, \\ Turkey
}

\begin{abstract}
We report here a patient with type 1 Duane's retraction syndrome and multiple congenital abnormalities as a result of the VACTERL association. The presented combination of Duane's retraction syndrome and the VACTERL association has not been reported in the literature. The present case was instructive for reviewing the continuous spectrum of ocular anomalies that accompany the VACTERL association.
\end{abstract}

Keywords: Duane's retraction syndrome, VACTERL association, combination

\section{Introduction}

The VATER association was first described in 1973 as the nonrandom co-occurrence of five defects, ie, vertebral anomalies (V), anal atresia (A), esophageal atresia and/or trachea-esophageal fistula (TE) and radial and renal anomalies (R). Subsequently, cardiovascular anomalies (C) and limb defects (L) were also included, defining the acronym VACTERL association. ${ }^{1,2}$ Although numerous syndromes associated with VACTERL have been identified, the etiology remains unknown. ${ }^{3,4}$

Duane's retraction syndrome is a congenital oculomotor anomaly that is accompanied by retraction of the globe and characterized by simultaneous narrowing of the palpebral fissure on attempted adduction, limitation of abduction, slight limitation of adduction, and elevation or depression of the globe during adduction. ${ }^{5}$ Patients with Duane's retraction syndrome have a 10-20 times greater risk of having other congenital malformations. ${ }^{6}$

In the present report, we describe the unusual occurrence of type 1 Duane's retraction syndrome with multiple congenital abnormalities due to the VACTERL association.

\section{Case report}

A 2-year-old child was referred to the Strabismus Department at the Prof Dr N Reşat Belger Beyoglu Education and Research Eye Hospital for evaluation of strabismus. This female infant was the first child of nonconsanguinous parents, and her family history was negative for congenital anomalies. The mother was 29 years old and the father was 30 years old. The mother had no history of diabetes or exposure to teratogenic agents, such as lead, lovastatin, dibenzepin, or exogenous sex hormones. There was no history of smoking, alcohol, drug abuse, or any infectious disease. The child, who had a normal prenatal ultrasound at 14 weeks' gestation, was born after an otherwise uncomplicated pregnancy. A triple test was not performed on the mother 
during her pregnancy. A cesarean section was performed at 38 weeks. The infant's weight and length at birth were $2720 \mathrm{~g}$ and $44 \mathrm{~cm}$, respectively. Her head circumference was not measured at that time.

At the pediatric surgery consultation, a perineal fistula, anterior anal ectopia, and anal stenosis were detected. Renal problems included a crossed fused renal ectopic duplicate kidney on the left side, renal agenesis on the right side (on intravenous pyelogram), and grade 2 vesicoureteral reflux (on voiding cystourethrogram). At the neurological consultation, the motor function of the upper extremities was normal, but a motor deficit was determined in the left lower extremity. Left ankle plantar flexion and dorsiflexion were $0 / 5$ with an absent Achilles reflex. Magnetic resonance imaging of the cervical and dorsolumbar spine revealed partial fusion of the D5-D6 vertebrae, hemivertebrae and partial fusion of L4-L5-S1, scoliosis (dorsolumbar to right, lumbosacral to left), spina bifida at the L4-S1 level, a tethered spinal cord combined with intradural lipoma at the L3-L4 level, and syringomyelia at the L2-L3 level. Major limb malformation included shortness of the left lower limb, primarily due to hypoplasia of the stylopod and zeugopod, hypoplasia of muscles, and subcutaneous fatty tissue in these two parts, pes equinovarus on the left side, and impaired movement of the left genu with a $90^{\circ}$ flexion contracture of the left knee, and a hypoplastic thumb and fingers on the left side. A radiographic evaluation confirmed the previously identified malformations and also demonstrated a short tibia and femur, malformed carpal bones, and hypoplasia of all skeletal components of the second ray on the left lower limb. Dysgenesis of the left hemipelvis and sacrum, dysplasia of the left femur, and hypoplasia of muscles in the front and back of thigh were identified on magnetic resonance imaging of the hip (Figure 1A and B). She had low-set microtia on the left side (Figure 1C); furthermore, pure tone audiometry revealed a $60 \mathrm{~dB}$ hearing level in the left ear and a normal range of hearing in the right ear. An echocardiogram did not show any intracardiac anomalies.

The patient and her family were referred to the Department of Medical Genetics. The girl had a normal female karyotype (46, XX) in cultured blood lymphocytes. Her chromosomal analysis, based on 400-550 bands per haploid karyotype, did not reveal any abnormalities. There was no family history of eye or genetic defects, and her
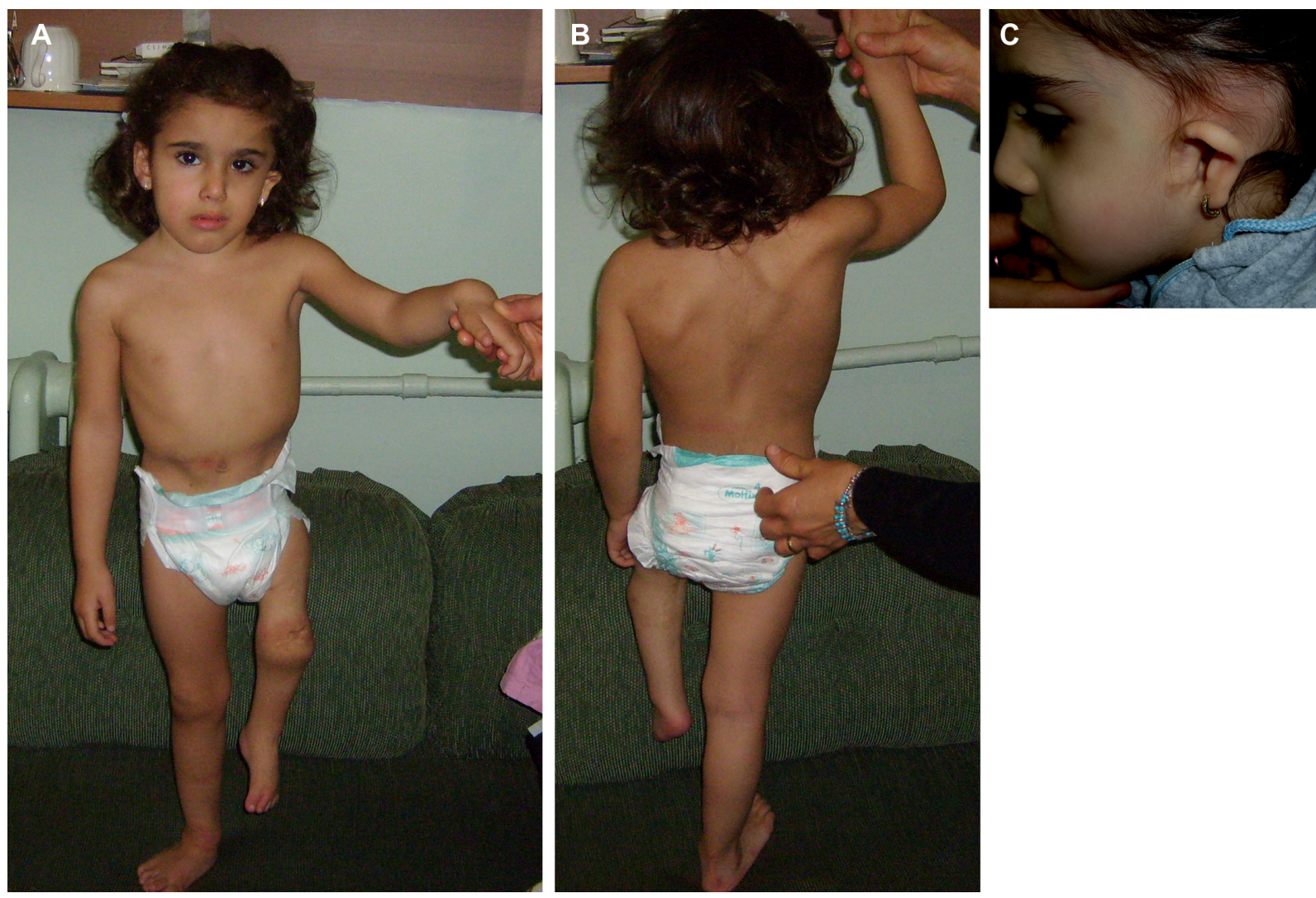

Figure I (A) Front view of the patient, showing facial asymmetry, pes equinovarus on the left side, a 90 degree flexion contracture of the left knee, and marked shortness of the lower limb. Hypoplasia of the muscles and subcutaneous fat in the stylopod with overt reduction of the limb circumference were also noted. (B) Back view of the patient, showing scoliosis and tethered cord. (C) A low-set left ear and atretic pinna (left microtia). 
parents' karyotypes were normal. She had no chromosomal abnormalities or known genetic disorders, such as Fanconi syndrome, Feingold syndrome, Baller-Gerold syndrome, or germline mutation in the PTEN gene.

The ophthalmic examination revealed a corrected visual acuity of $16 / 20$ in the right eye and 20/20 in the left eye. The pupils were equal, round, and reactive to light, with no evidence of a relative afferent pupillary defect. The cycloplegic refraction value was $+3.50,-1.00 \alpha 15^{\circ}$ in the right eye and $+3.75,-1.00 \alpha 40^{\circ}$ in the left eye. On motility examination, we determined $15 \Delta$ esotropia via the Krimsky method. Slit-lamp biomicroscopy revealed normal anterior and posterior segments in both eyes. The intraocular pressures were normal. The patient had a -2 restriction on right abduction, narrowing of the palpebral fissures, globe retraction, and upshoot on attempted adduction. The other versions and ductions were normal. The patient exhibited facial asymmetry. The ophthalmological examination revealed type 1 Duane's retraction syndrome in the right eye (Figure 2A).

At 5 months of age, the infant underwent surgery for her tethered cord. At one year of age, she underwent an operation for flexion contracture of her left knee. The patient received a staged reconstruction surgery under colostomy. She underwent anal transposition surgery and posterior sagittal anorectoplasty at 18 months of age. The colostomy remained open until healing from the posterior sagittal anorectoplasty was achieved. After healing was completed, the colostomy was closed. The patient had lack of continence which improved after the surgery. At 4 years of age, she underwent a left ear operation.

Strabismus surgery was performed when the patient was 2 years of age, with no complications. She underwent a right medial rectus recession ( $5 \mathrm{~mm}$ ) operation. Postoperatively, the patient was orthotropic in the primary position. She had no globe retraction or upshoot on attempted adduction and $\mathrm{a}-1$ restriction of right abduction (Figure 2B).

\section{Discussion}

The VATER association describes a rare condition characterized by a sporadic combination of specific birth defects. The VATER or VACTERL association (an acronym for vertebral defects, anorectal malformations, cardiac defects, tracheo-esophageal fistulas, renal anomalies, and limb anomalies) represents a statistically related pattern of associated anomalies. The diagnosis of a VACTERL association is made when three or more features of the association are present. ${ }^{3}$ The most commonly associated anomalies in these patients are anorectal malformations (55\%-90\%), tracheo-esophageal fistulas (50\%-80\%), renal anomalies $(50 \%-80 \%)$, vertebral anomalies $(36 \%-80 \%)$, cardiac anomalies (40\%-80\%), and limb anomalies $(40 \%-50 \%) .{ }^{7,8}$ Lower limb defects do occur in the VATER association but are far less frequent than upper limb defects. ${ }^{9}$ Our case displayed four characteristics of the VACTERL association, including anorectal, renal, vertebral, and lower limb defects. In addition, she had auricular atresia of the left ear. Vertebral anomalies can occur in any segment of the spine and may be associated with neurologic abnormalities. ${ }^{10}$ Our patient had tethered cord syndrome. In this syndrome, neurological deficits are generally irreversible. In children, early surgery is recommended to prevent further neurological deterioration. ${ }^{11-13}$ We determined some neurological deficits early, so we performed tethered cord surgery at 5 months of age.

Although numerous etiologies are known to be responsible for the VATER/VACTERL association, the pathogenesis remains unknown in the majority of cases. ${ }^{2}$
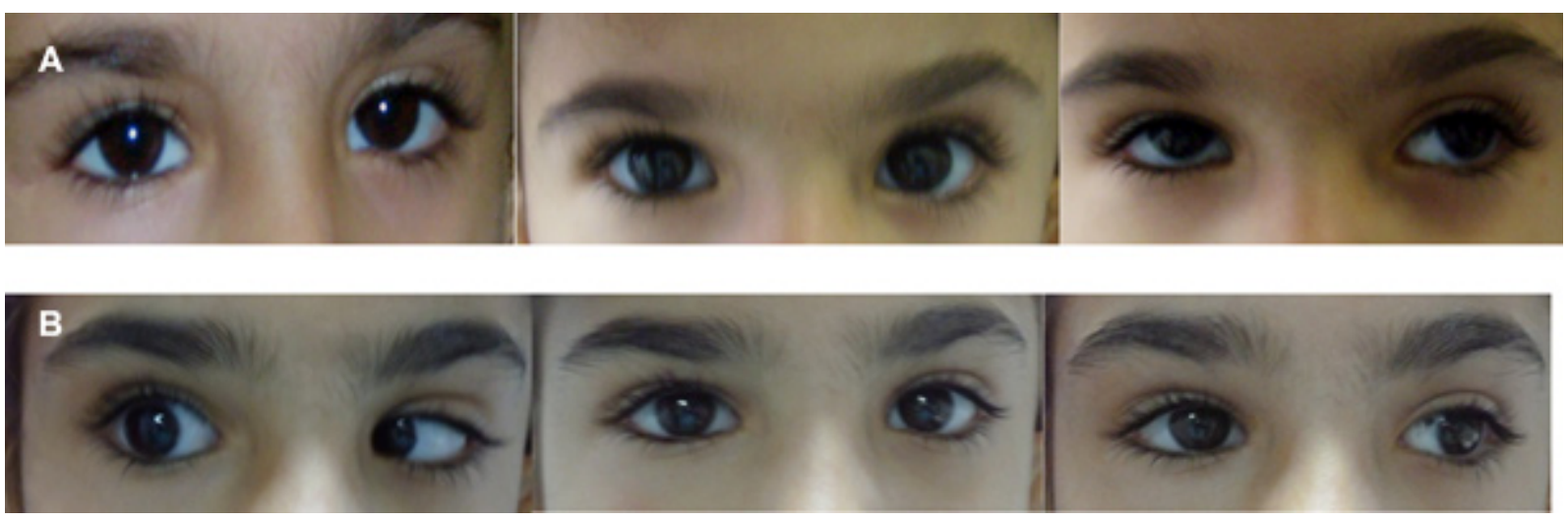

Figure 2 Right type I Duane's syndrome. (A) Preoperative appearance ( -2 restriction on abduction, narrowing of the palpebral fissures, globe retraction, and upshoot on attempted adduction of right eye). (B) Postoperative appearance (-I restriction of right abduction, no globe retraction or upshoot, orthotropic in primary position). 
This association has also been described as the result of teratogenic exposures, such as lead, lovastatin, dibenzepin, maternal diabetes, exogenous sex hormones, chromosomal abnormalities such as $\operatorname{Del}(6) \mathrm{q}, 9 \mathrm{q}+$, supernumerary ring chromosome, and Del(13)(q31.1qter), and known genetic disorders such as Fanconi syndrome, Feingold syndrome, Baller-Gerold syndrome, and germline mutation in the PTEN gene. ${ }^{14-22}$ A primary developmental field defect resulting from failure of mesodermal cell migration during early blastogenesis ie, during the first 4 weeks of development has been suspected, ${ }^{3,4}$ as well as a multifactorial origin. ${ }^{23}$ However, in our case, no teratogenic exposures, chromosomal abnormalities, or known genetic disorders could be recognized. The rare familial occurrence of VATER/ VACTERL association is in favor of a genetic origin with either autosomal dominant or recessive mode of inheritance. ${ }^{24}$ Moreover, recently, the observation of VATER/VACTERL association in a Gli mutant mouse has suggested that impairment of the sonic hedgehog pathway could also be responsible for this phenotype. ${ }^{25}$ Some authors have reported that the VATER/VACTERL association has been described as a result of respiratory chain deficiency. ${ }^{2}$

Patients with the VACTERL association have eye defects. ${ }^{26}$ Their ophthalmic findings include ptosis, strabismus, myopia, hypermetropia, amblyopia, anisometropia, cloudy corneas, microcornea, congenital corneal anesthesia (ie, recurrent erosions, keratitis, ulcers, and leukomas), anisocoria and heterochromia iridis, cataracts, and lacrimal system abnormalities. $^{26-28}$ The most common associations are coloboma and microphthalmos. ${ }^{27}$ The retina and posterior segment are seldom involved. A unique case of Coats' disease combined with the VATER association has been reported. ${ }^{29}$ To our knowledge, there have been no reports of a patient with Duane's retraction syndrome and the VACTERL association. In the present case study, we report the unusual occurrence of type 1 Duane's retraction syndrome in a child with the VACTERL association. Duane's retraction syndrome is a congenital disorder of eye motility. The pathogenetic mechanism of this syndrome is abnormal rectus innervation of the affected eye by axons that are destined for the medial rectus. ${ }^{5,6}$ Genetic and environmental factors may be responsible for Duane's retraction syndrome, ${ }^{6}$ but these causes had been ruled out in our case. The gene responsible for the gene has been mapped to $8 \mathrm{q} 13.3 .{ }^{30}$ Specification of mammalian motor neurons and mutations in the Pax 6 gene may be responsible for the aberrant innervation in Duane's retraction syndrome. ${ }^{31}$ The Pax gene family consists of developmental control genes and plays an important role in the development of the vertebral column, genitourinary tract, and central nervous system. ${ }^{32}$ In our patient, chromosomal analysis did not reveal any aberrations. In the majority of cases of VACTERL association, the pathogenesis remains unknown. ${ }^{3,4}$

In conclusion, our patient presented an unusual combination of Duane's retraction syndrome and VACTERL association, which has not been previously reported. This case is instructive for reviewing the continuous spectrum of ocular anomalies that accompany the VACTERL association. The cause of the association between VATER/VACTERL and Duane syndrome is not clear, but these two syndromes might be the result of defective mesodermal development during embryogenesis.

\section{Acknowledgments}

The authors would like to acknowledge the generous and helpful assistances of Serdar Sander from the Department of Pediatric Surgery, Istanbul Kanuni Sultan Süleyman, Training and Research Hospital, and Serdar Cevik, from the Department of Neurosurgery, Medical Faculty, Bezmi Alem Foundation University. The authors obtained parental consent to use the images shown.

\section{Disclosure}

The authors report no conflicts of interest in this work.

\section{References}

1. Quan L, Smith DW. The VATER association. Vertebral defects, anal atresia, T-E fistula with esophageal atresia, radial and renal dysplasia: a spectrum of associated defects. J Pediatr. 1973;82:104-107.

2. Thauvin-Robinet C, Faivre L, Huet F, et al. Another observation with VATER association and a complex IV respiratory chain deficiency. Eur J Med Genet. 2006;49:71-77.

3. Martinez-Frias ML, Frias JL. VACTERLY as primary, polytopic developmental field defects. Am J Med Genet. 1999;83:13-16.

4. Martinez-Frias ML, Frias JL. Primary developmental field III: clinical and epidemiological study of blastogenetic anomalies and their relationship to different MCA patterns. Am J Med Genet. 1997;70:11-15.

5. Von Noorden GK, Campos E. Special forms of strabismus. In: Binocular Vision and Ocular Motility: Theory and Management of Strabismus, 6th ed. St Louis, MO: Mosby; 2002.

6. Pfaffenbach DD, Cross HE, Kearns TP. Congenital anomalies in Duane's retraction syndrome. Arch Ophthalmol. 1972;88:635-639.

7. Chittmittrapap S, Spitz L, Kiely EM, et al. Oesophageal atresia and associated anomalies. Arch Dis Childhood. 1989;64:364-368.

8. Solomon BD. VACTERL/VATER association. Orphanet J Rare Dis. 2011;6:56.

9. Fernbach SK, Glass RBJ. The expanded spectrum of limb anomalies in the VATER association. Pediatr Radiol. 1988;18:215-220.

10. Barnes JC, Smith WL. The VATER association. Radiology. 1978;126: 445-449.

11. Boop FA, Russell A, Chadduck WM. Diagnosis and management of the tethered cord syndrome. J Ark Med Soc. 1992;89:328-331.

12. Iskandar BJ, Fulmer BB, Hadley MN, Oakes WJ. Congenital tethered spinal cord syndrome in adults. J Neurosurg. 1998;88:958-961.

13. van Leeuwen R, Notermans NC, Vandertop WP. Surgery in adults with tethered cord syndrome: outcome study with independent clinical review. J Neurosurg. 2001;94:205-209. 
14. Levine F, Muenke M. VACTERL association with high prenatal lead exposure; similarities to animal models of lead teratogenicity. Pediatrics. 1991;87:390-392.

15. Ghidini A, Sicherer S, Willner J. Congenital abnormalities (VATER) in a baby born to a mother using lovastatin. Lancet. 1992;339:1416-1417.

16. Merlob P, Naor N. Drug induced VATER association: is dibenzepin a possible cause? J Med Genet. 1994;31:423.

17. Loffredo CA, Wilson PD, Ferencz C. Maternal diabetes: an independent risk factor for majör cardiovascular malformations with increased mortality of affected infants. Teratology. 2001;64:98-106.

18. Kaufmann RL. Birth defects and oral contraceptives. Lancet. 1973;1: 1396.

19. Cinti R, Priolo M, Lerone M, et al. Molecular characterisation of a supernumerary ring chromosome in a patient with VATER association. J Med Genet. 2001;38:1-4.

20. McNeal RM, Skoglund RR, Francke U. Congenital anomalies including the VATER association in a patient with a del(6)q deletion. J Pediatr. 1977;91:957-960.

21. Celli J, van Bokhoven H, Brunner HG. Feingold syndrome: clinical review and genetic mapping. Am J Med Genet A. 2003;122A:294-300.

22. Reardon W, Zhou XP, Eng C. A novel germline mutation of the PTEN gene in a patient with macrocephaly, ventricular dilatation, and features of VATER association. J Med Genet. 2001;38:820-823.

23. Khoury MJ, Cordero JF, Greenberg F, et al. A population study of the VACTERL association: evidence for its etiologic heterogeneity. Pediatrics. 1983;71:815-820.
24. Auchterlonie IA, White MP. Recurrence of the VATER association: within a sibship. Clin Genet. 1982;21:122-124.

25. Martínez-Frias ML, Bermejo E, Frias JL. The VACTERL association: lessons from the sonic hedgehog pathway. Clin Genet. 2001;60: 397-398.

26. Say B, Greenberg D, Haris R, Delong SL, Coldwell JG. The radial dysplasia/imperforate anus/vertebral anomalies syndrome (the VATER association): developmental aspects an deye findings. Acta Paediatr Scand. 1977;66:233-235.

27. Kallen K, Robert E, Castilla EE, Mastroiacovo P, Kallen B. Relation between oculo-auriculo-vertebral (OAV) dysplasia and three other non-random associations of malformations (VATER, CHARGE, and OEIS). Am J Med Genet A. 2004;127A:26-34.

28. Harrison AR, Dailey RA, Wobig JL. Bilateral congenital lacrimal anlage ducts (lacrimal fistula) in a patient with the VACTERL association. Ophthal Plast Reconstr Surg. 2002;18:149-150.

29. Hon C, Ko TC. Coats disease and VATER association in a 5-year-old boy. Arch Ophthalmol. 2004;122:1232-1233.

30. OMIM $^{\mathrm{TM}}$. Mendelian Inheritance in Man. MIM Number 126800 Baltimore, MD: Johns Hopkins University; 2004. Available from: http://www.ncbi.nlm.nih.gov/omim/. Accessed February 22, 2013.

31. Osumi N, Hirota A, Ohuchi H, et al. Pax-6 is involved in the specification of hindbrain motor neuron subtype. Development. 1997;124: 2961-2972.

32. Strachan T, Read AP. Pax genes. Curr Opin Genet Dev. 1994;4: $427-438$.
Clinical Ophthalmology

\section{Publish your work in this journal}

Clinical Ophthalmology is an international, peer-reviewed journal covering all subspecialties within ophthalmology. Key topics include: Optometry; Visual science; Pharmacology and drug therapy in eye diseases; Basic Sciences; Primary and Secondary eye care; Patien Safety and Quality of Care Improvements. This journal is indexed on

Submit your manuscript here: http://www.dovepress.com/clinical-ophthalmology-journal

\section{Dovepress}

PubMed Central and CAS, and is the official journal of The Society of Clinical Ophthalmology (SCO). The manuscript management system is completely online and includes a very quick and fair peer-review system, which is all easy to use. Visit http://www.dovepress.com/ testimonials.php to read real quotes from published authors. 